\title{
The Investigation of Self Directed Learning Skills of Teachers In Kartepe (The District of Kocaeli In Turkey) : A Qualitative Study
}

Funda Arslan ${ }^{1}$

\section{ARTICLE INFO}

Article History:

Received 05.03.2019

Received in revised form

31.05.2019

Accepted

Available online 01.10.2019

\begin{abstract}
In this study, it is aimed to examine the opinions of teachers' self-directed learning skills with semi-structured interview form. The participants include 40 teachers from a primary and two secondary schools in Kartepe ( the district of Kocaeli). Self-Directed Learning Interview Form which has been designed by reading the relevant literature and seeking the experts' opinions includes five questions related to phases of Self Direction in learning. The form was administered teachers face to face mostly.The interviews were audiorecorded and then transcribed by the researchers. The results of this represent each phase of Self-Directed Learning and also consistent with the studies in the literature.
\end{abstract}

C IJERE. All rights reserved

Keywords: ${ }^{1}$

Self-Directed Learning ,Teacher'Opinions,A Qualitative Study

\section{Introduction}

Self-directed learning has been an effective learning concept for over thirty years in adult education. Self- direction in adult learning is called self-teaching, self-planning, independent adult learning, selfmanagement and self-initiation (Owen, 2002). Self-directed learning was first argued in North America in the early 1960s by adult education and androgogy experts and was defined as a teaching process in which the student took over the basic responsibilities of planning, implementation and organization. (Brockett and Hiemstra, 1991; Benson, 2001). It is generally regarded as a concept related to learning activities such as goal setting, planning a learning strategy, accessing resources and monitoring progress. (Ponton ve Carr, 2000).

In terms of its relationship with Andragogy, self-directed learning theory discusses that adults have a need and capacity to guide their learning efforts themselves. Process and personality elements should be considered in self-directed learning situations. The willingness and ability to take responsibility for and control over learning decisions connect these two elements. The self-directed learning process, involving planning, implementation and evaluation of learning, is influenced by the context in which learning occurs. Self-directed learning activities can be carried out independently and collaboratively. Because adults have different levels of readiness and abilities to self-direct their learning, they may need support in the process. Adult learners who have characteristics of self-directed learners pick self-directed learning activities on a situational basis. (Porter, 2014).In related to self-directed learning, Hiemstra and Brockett (2012) noted that "over the past several decades, self-directed learning (SDL) has been one of the most active areas of inquiry within adult education and learning" (p. 155). Merriam (2001) said, "Clearly, there are numerous possibilities for how future research on self-directed learning might enrich adult education practice as well as contribute to theory in adult learning" (p. 11). The aim of this study was to investigate the relationship between teachers' lifelong learning and self-directed learning skills. In the literature, lifelong learning skills, qualifications and levels of teachers, especially teacher candidates, were examined both quantitatively and qualitatively by various variables. Although it hasn't been studied as much as lifelong learning ; self-directed learning has been the subject of many different studies in terms of readiness level.

Although self-directed learning skills of teachers are subject to several researches in terms of various variables, this study will provide a different and unique vision to literature which will support the relationship between teachers' lifelong learning and self-directed learning skills by qualitatively in terms of gender, branch and especially the lenght of service.

The aim of this study was to investigate the relationship between teachers' lifelong learning and selfdirected learning skills. In the literature, lifelong learning skills, qualifications and levels of teachers,

\footnotetext{
${ }^{1}$ Corresponding e-mail: funda.arslan@ogr.sakarya.edu.tr ,Sakarya University, orcid.org/0000-0001-7365-808X
} 
especially teacher candidates, were examined both quantitatively and qualitatively by various variables. Although it hasn't been studied as much as lifelong learning; self-directed learning has been the subject of many different studies in terms of readiness level.

Although self-directed learning skills of teachers are subject to several researches in terms of various variables, this study will provide a different and unique vision to literature which will support the relationship between teachers' lifelong learning and self-directed learning skills by qualitatively in terms of gender, branch and especially the lenght of service.

\section{Method}

The qualitative study was applied in this study. The case study from the qualitative study group is the analysis by providing a holistic view of one or more conditions (Yıldırım \& Şimşek, 2013).

This qualitative study which investigates the opinions of teachers on their self-directed learning skills is composed of 40 teachers working in a primary and two secondary schools in Kartepe (the district of Kocaeli) in the academic year of 2017-2018. Frequency distribution of teachers, taking part in the present study, in terms of variables was shown in Table 1.

Table 1 . Frequency Distribution of Teachers with In Terms of Variables

\begin{tabular}{|c|c|c|c|}
\hline & & Number & $\%$ \\
\hline \multirow{3}{*}{ Gender } & Male & 16 & 36,36 \\
\hline & Female & 28 & 6 \\
\hline & $1-5$ year & 16 & 36,36 \\
\hline \multirow{4}{*}{ The lenght of service } & $6-10$ year & 15 & 34,09 \\
\hline & $11-15$ year & 5 & 11,36 \\
\hline & $16-20$ year & 2 & 4 \\
\hline & More than 21 year & 6 & 13,63 \\
\hline \multirow{4}{*}{ Branches } & Teachers of Linguistic Skills & 20 & 45,45 \\
\hline & Teachers of Logical - Mathematical Skills & 8 & 18,18 \\
\hline & Teachers of Special Talents & 5 & 11,36 \\
\hline & Primary School Teachers & 11 & 22,72 \\
\hline
\end{tabular}

\section{Material}

In this qualitative study, a semi-structured interview form designed by the researchers was used. "Self Directed Learning Interview Form " was designed with the aim of exploring the teachers' opinions about self directed learning by reading the relevant literature and seeking the experts' opinions. The suggestions of the experts in this field were taken into account while designing the interview form. The form was piloted and its validity and reliability were tested. It consisted of two parts. In the first part, the participants' gender, age,branch and the lenght of service were asked. In the second part, there were five questions regarding the opinions of teachers on self directed learning.

In the process of data collection, after the permission for access had been gained from the Ministry of Education of Kartepe (the district of Kocaeli), a primary - two secondary school were visited and the data collection instrument was introduced to the teachers. During this process, the participants were informed 
Arslan,F. (2019). The investigation of self directed learning skills of teachers in Kartepe (The District of Kocaeli In Turkey) : A qualitative study. International Journal of Educational Research Review,4(4),525-535.

about the importance of providing the researcher true information. The form was administered teachers face to face mostly. The interviews were audiorecorded. Each interview took about 10 minutes. For the purpose of investigating the teachers' opinions about self directed learning, the interviews were audiorecorded and then transcribed by the researchers.

\section{Findings}

1. The opinions of the teachers regarding the question of "What are the opinions of teachers on their individual and professional development in the lifelong learning process?"

The frequency results of the opinions of the teachers regarding the question of "What are the opinions of teachers on their individual and professional development in the lifelong learning process?" are given as follows.

Table 2. The opinions of teachers regarding their individual and professional development in the lifelong learning process.

\begin{tabular}{|c|c|c|c|}
\hline $\begin{array}{l}\text { Theme } \\
\text { (Categories) }\end{array}$ & Codes & $f$ & $\%$ \\
\hline \multirow[t]{7}{*}{$\begin{array}{l}\text { Individual } \\
\text { Development }\end{array}$} & $\begin{array}{l}\text { Art and Socio Cultural Activities } \\
\text { (chess, cinema, instrument, folk dances, concert) } \\
\mathrm{T} 4, \mathrm{~T} 13, \mathrm{~T} 20, \mathrm{~T} 24, \mathrm{~T} 27, \mathrm{~T} 28, \mathrm{~T} 44, \mathrm{~T} 1, \mathrm{~T} 40, \mathrm{~T} 2, \mathrm{~T} 26, \mathrm{~T} 35 \\
\mathrm{~T} 36, \mathrm{~T} 33, \mathrm{~T} 31\end{array}$ & 15 & 34,09 \\
\hline & $\begin{array}{l}\text { Reading about personal development and interest } \\
\mathrm{T} 17, \mathrm{~T} 33, \mathrm{~T} 1, \mathrm{~T} 31, \mathrm{~T} 39, \mathrm{~T} 35, \mathrm{~T} 26, \mathrm{~T} 18, \mathrm{~T} 44\end{array}$ & 9 & 20,45 \\
\hline & $\begin{array}{l}\text { Cultural Trips } \\
\mathrm{T} 13, \mathrm{~T} 24, \mathrm{~T} 27, \mathrm{~T} 12, \mathrm{~T} 26, \mathrm{~T} 5, \mathrm{~T} 44\end{array}$ & 7 & 15,90 \\
\hline & $\begin{array}{l}\text { Types of Verbal Lecture } \\
\text { (Interviews, conferences, panels, symposiums) } \\
\mathrm{T} 24, \mathrm{~T} 3, \mathrm{~T} 42, \mathrm{~T} 35, \mathrm{~T} 15, \mathrm{~T} 5\end{array}$ & 6 & 13,63 \\
\hline & $\begin{array}{l}\text { Physical development activities } \\
\text { (Sports, yoga, swimming) } \\
\mathrm{T} 4, \mathrm{~T} 13, \mathrm{~T} 40, \mathrm{~T} 26, \mathrm{~T} 21\end{array}$ & 5 & 11,36 \\
\hline & $\begin{array}{l}\text { Participating in the activities being interested } \\
\mathrm{T} 29, \mathrm{~T} 34, \mathrm{~T} 43, \mathrm{~T} 21\end{array}$ & 4 & 9,09 \\
\hline & $\begin{array}{l}\text { Keeping updated on the latest developments } \\
\mathrm{T} 19, \mathrm{~T} 27\end{array}$ & 2 & 4,54 \\
\hline $\begin{array}{l}\text { Professional } \\
\text { Devlopment }\end{array}$ & $\begin{array}{l}\text { Participation in seminars, in-service and distance trainings } \\
\mathrm{T} 4, \mathrm{~T} 6, \mathrm{~T} 7, \mathrm{~T} 9, \mathrm{~T} 8, \mathrm{~T} 13, \mathrm{~T} 19, \mathrm{~T} 20, \mathrm{~T} 24, \mathrm{~T} 25, \mathrm{~T} 30, \mathrm{~T} 37, \mathrm{~T} 41 \\
\mathrm{~T} 3, \mathrm{~T} 1, \mathrm{~T} 2, \mathrm{~T} 40, \mathrm{~T} 35, \mathrm{~T} 32, \mathrm{~T} 5, \mathrm{~T} 10, \mathrm{~T} 18, \mathrm{~T} 44\end{array}$ & 23 & 52,27 \\
\hline
\end{tabular}




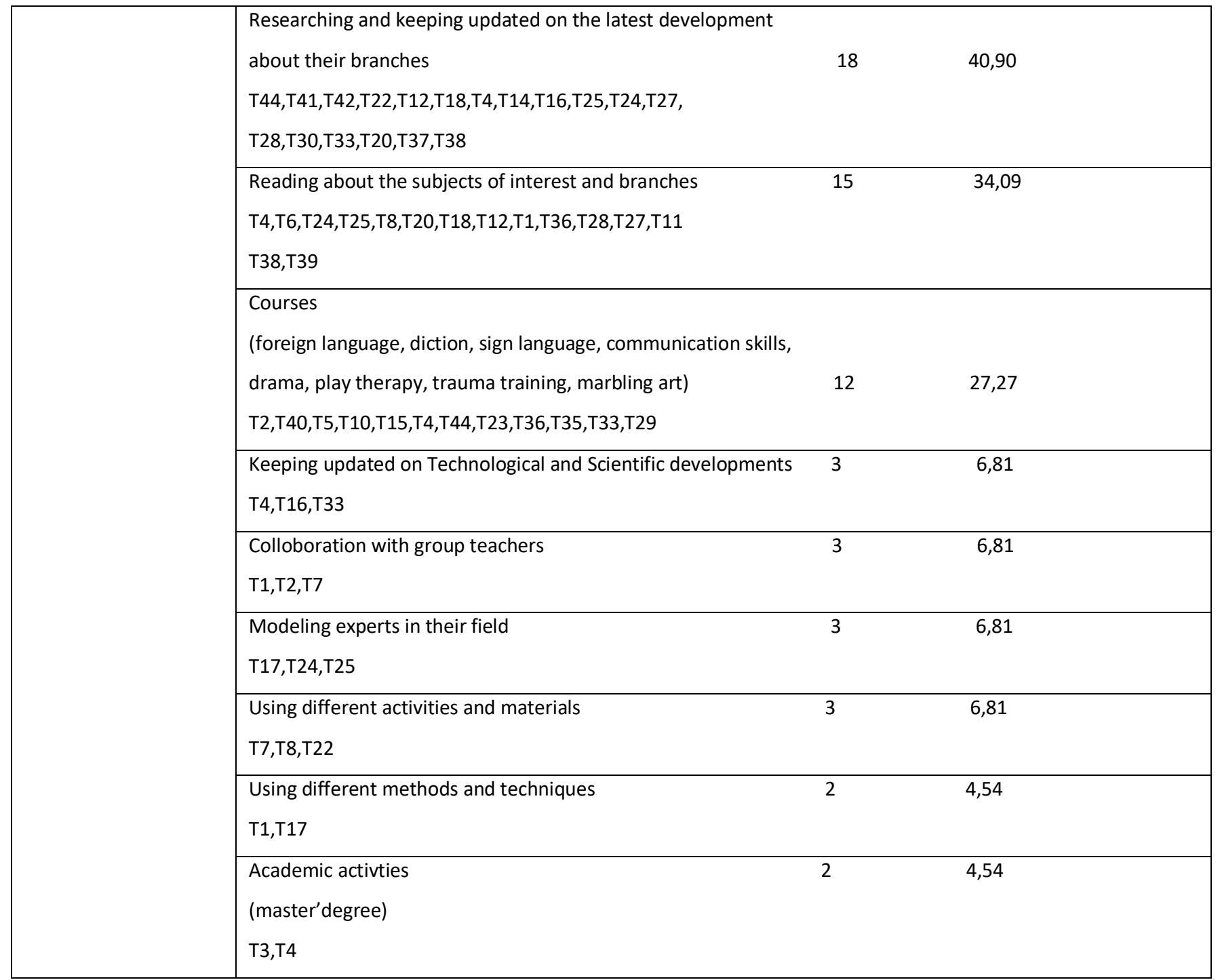

When the Table 2 is analyzed,It is understood that while teachers mostly prefer "Art and Socio Cultural Activities (chess, cinema, instrument, folk dances, concert)" then reading about personal development and interest regarding their individual development in the lifelong learning process.They tend "participation in seminars, in-service and distance trainings" at first ;"researching and keeping updated on the latest development about their branches" secondly in terms of their Professional development in the lifelong learning process.

Quotations from teachers' opinions are given below.

I follow the seminars and trainings that will contribute to my professional development. I have a chat with friends who are interested in same issues and who are in the same profession by reading magazines and books or watching movies. I went to sign language, marbling and binding course. I try to participate in activities such as theater,movies and concerts . (T2)

I believe in the importance of reading, questioning and research for my individual development. I know the importance of the sense of wonder and I try to learn everything I wonder.I suppose that physical development is as 
Arslan,F. (2019). The investigation of self directed learning skills of teachers in Kartepe (The District of Kocaeli In Turkey) : A qualitative study. International Journal of Educational Research Review,4(4),525-535.

important one's life as mental development.considering that physical activities such as doing sports are also important with the most common saying " a healty mind in a healty body" First of all, I strongly agree with benefitting the experiences of profession experts for my Professional development. I am interested in learning and using educational technologies to keep up with the innovations of the developing and changing age. In addition, I intend to go beyond the classical Turkish teacher model by preparing the books and educational materials that will enrich the curriculum as soon as possible."T21

I try to follow current events both on the news and on the internet in order to improve myself in an individual sense,. I'm trying to participate in socio-cultural activities.I am learning the diffentt accents and terminology of English language. There are also different languages I am trying to learn. I follow the scientific and technological developments. The psychology.of Education and Learning is my biggest interest.I try to read books and articles about it."I have just had my master's degree.T4

\section{The opinions of the teachers regarding the question of "What are the opinions of teachers on how they} plan their learning activities?

The frequency results of the opinions of the teachers regarding the question of "What are the opinions of teachers on how they plan their learning activities? are given as follows.

Table 3. The opinions of teachers regarding What are the opinions of teachers on how they plan their learning activities?

\begin{tabular}{|c|c|c|c|}
\hline $\begin{array}{l}\text { Themes } \\
\text { (Categories) }\end{array}$ & Codes & $f$ & $\%$ \\
\hline Planning & Planning according to topics of interest & & \\
\hline Learning & $\mathrm{T} 43, \mathrm{~T} 2, \mathrm{~T} 1, \mathrm{~T} 3, \mathrm{~T} 36, \mathrm{~T} 33, \mathrm{~T} 19, \mathrm{~T} 17, \mathrm{~T} 16, \mathrm{~T} 14, \mathrm{~T} 9, \mathrm{~T} 18, \mathrm{~T} 22, \mathrm{~T} 44$ & 14 & 31,81 \\
\hline \multirow[t]{8}{*}{ Activities } & $\begin{array}{l}\text { Planning in terms of bearing profit professionally } \\
\text { T43,T2,T1,T3,T36,T33,T19,T17,T16,T14,T9,T18,T22 } \\
\text { T44 }\end{array}$ & 14 & 31,81 \\
\hline & $\begin{array}{l}\text { Planning according to the learning needs } \\
\mathrm{T} 38, \mathrm{~T} 2, \mathrm{~T} 3, \mathrm{~T} 41, \mathrm{~T} 37, \mathrm{~T} 36, \mathrm{~T} 30, \mathrm{~T} 24, \mathrm{~T} 20, \mathrm{~T} 17, \mathrm{~T} 16, \mathrm{~T} 18, \mathrm{~T} 32\end{array}$ & 13 & 29,54 \\
\hline & $\begin{array}{l}\text { Planning according to personal development and satisfaction } \\
\mathrm{T} 36, \mathrm{~T} 23, \mathrm{~T} 29, \mathrm{~T} 28, \mathrm{~T} 27, \mathrm{~T} 13, \mathrm{~T} 8, \mathrm{~T} 4, \mathrm{~T} 21, \mathrm{~T} 11, \mathrm{~T} 5, \mathrm{~T} 26, \mathrm{~T} 44\end{array}$ & 13 & 29,54 \\
\hline & $\begin{array}{l}\text { Planning according to being practical } \\
\text { (in exam, in daily life) } \\
\text { T44,T11,T4,T43,T25,T20,T8,T10,T35 }\end{array}$ & 9 & 20,45 \\
\hline & $\begin{array}{l}\text { Depending on availability of working hou } \\
\text { T7,T6,T10,T24,T23,T44 }\end{array}$ & 6 & 13,63 \\
\hline & $\begin{array}{l}\text { Planning in line with technological and scientific developments } \\
\text { T33,T42,T14,T15,T32 }\end{array}$ & 5 & 11,36 \\
\hline & $\begin{array}{l}\text { Planning according to the subjects' interests } \\
\text { and the needs of the learner } \\
\mathrm{T} 40, \mathrm{~T} 12, \mathrm{~T} 22\end{array}$ & 3 & 6,81 \\
\hline & $\begin{array}{l}\text { Planning information based on persistence } \\
\text { T25 }\end{array}$ & 1 & 2,27 \\
\hline
\end{tabular}




\begin{tabular}{|c|c|c|c|}
\hline & $\begin{array}{l}\text { Planning according to the environment } \\
\text { T38 }\end{array}$ & 1 & 2,27 \\
\hline
\end{tabular}

When the Table 3 is analyzed, It is understood that teachers mostly plan their activities according to topics of interest then bearing profit professionally .

Quotations from teachers' views are given below.

"I prefer to focus on the subjects I am interested in and I need while teaching". T16

"My aim in learning is mostly in behalf of my individual and professional development. I have difficulty in keeping learning what I am interested.I learn completely on my own request not wanting to have high grades. If I take an exam, I will diversify my learning environments. I enjoy working quietly in the middle of the morning and early evening. Since I have more stimuli during the day, I find it difficult to focus. I start to work what I am more interested in and able to do so I can spend more time on difficult subjects, but I'm still not good at time management. T3

"It is important to me what I will learn first is the subjects that I am interested in, which I love and need. I plan according to the topics that will help me improve myself and the learning techniques I like."T36

"My learning activities are based on my interests and skills that will benefit my professional development."T9

3.The opinions of the teachers regarding the question of ". What are the opinions of teachers on how they follow the learning process?

The frequency results of the opinions of the teachers regarding the question of ". What are the opinions of teachers on how they follow the learning process? are given as follows.

Table 4 . The opinions of teachers regarding "What are the opinions of teachers on how they follow the learning process?"

\begin{tabular}{|c|c|c|c|}
\hline $\begin{array}{l}\text { Theme } \\
\text { (Categories) }\end{array}$ & Codes & $f$ & $\%$ \\
\hline \multirow[t]{5}{*}{$\begin{array}{l}\text { Identifying a } \\
\text { learning strategy }\end{array}$} & $\begin{array}{l}\text { According to the effect on learning information } \\
\text { (being permanent, easy to remember) } \\
\text { T44,T21,T15,T35,T1,T43,T42,T29,T19, } \\
\mathrm{T} 23, \mathrm{~T} 24, \mathrm{~T} 25, \mathrm{~T} 28, \mathrm{~T} 33, \mathrm{~T} 3, \mathrm{~T} 16, \mathrm{~T} 8, \mathrm{~T} 10, \\
\mathrm{~T} 11, \mathrm{~T} 22, \mathrm{~T} 4, \mathrm{~T} 7\end{array}$ & 22 & 50 \\
\hline & $\begin{array}{l}\text { Determining according to the subject } \\
\text { (subject length, content) } \\
\text { T20,T35,T2,T43,T29,T17,T19,T24,T25 } \\
\text { T27,T34,T33,T36,T3,T38,T9,T22,T32 }\end{array}$ & 18 & 40,90 \\
\hline & $\begin{array}{l}\text { Making learning easier (putting into perspective, } \\
\text { in accordance with learning style) } \\
\mathrm{T} 35, \mathrm{~T} 43, \mathrm{~T} 30, \mathrm{~T} 31, \mathrm{~T} 23, \mathrm{~T} 24, \mathrm{~T} 27, \mathrm{~T} 28, \mathrm{~T} 34, \mathrm{~T} 41 \text {, } \\
\mathrm{T} 16, \mathrm{~T} 8, \mathrm{~T} 7, \mathrm{~T} 10, \mathrm{~T} 26, \mathrm{~T} 44\end{array}$ & 16 & 36,36 \\
\hline & $\begin{array}{l}\text { According to the time required } \\
\text { (time saving) } \\
\mathrm{T} 1, \mathrm{~T} 2, \mathrm{~T} 43, \mathrm{~T} 36, \mathrm{~T} 3, \mathrm{~T} 39, \mathrm{~T} 13, \mathrm{~T} 4\end{array}$ & 8 & 18,18 \\
\hline & $\begin{array}{l}\text { According to application and } \\
\text { transformation of knowledge } \\
\text { T18,T11,T5,T32 }\end{array}$ & 4 & 9,09 \\
\hline
\end{tabular}


Arslan,F. (2019). The investigation of self directed learning skills of teachers in Kartepe (The District of Kocaeli In Turkey) : A qualitative study. International Journal of Educational Research Review,4(4),525-535.

\begin{tabular}{|c|c|c|c|}
\hline \multirow[t]{4}{*}{$\begin{array}{l}\text { Evaluating } \\
\text { learning outcomes }\end{array}$} & $\begin{array}{l}\text { Self-assessment(repetation, asking questions, } \\
\text { narrating the subject) } \\
\mathrm{T} 17, \mathrm{~T} 27, \mathrm{~T} 14, \mathrm{~T} 6, \mathrm{~T} 7, \mathrm{~T} 8, \mathrm{~T} 15\end{array}$ & 7 & 15,90 \\
\hline & $\begin{array}{l}\text { Self-satisfaction } \\
\text { (satisfaction with the learning outcome,peace,happiness) } \\
\text { T20,T2,T3,T40,T10,T4,T35 }\end{array}$ & 7 & 15,90 \\
\hline & $\begin{array}{l}\text { Using assessment and evaluation techniques } \\
\text { (tests,exams) } \\
\text { T33,T10,T37,T8,T40,T21 }\end{array}$ & 6 & 13,63 \\
\hline & $\begin{array}{l}\text { Feedback from experts and peers } \\
\mathrm{T} 5, \mathrm{~T} 3, \mathrm{~T} 43\end{array}$ & 3 & 6,81 \\
\hline
\end{tabular}

When the Table 4 is analyzed, It is understood that teachers mostly identify their learning strategies "According to the its effect on learning information (being permanent, easy to remember) and then "determining according to the subject (subject length, content) in addition to evaluating learning outcomes first with Self-Assessment(repetation, asking questions ,narrating the subjects and then Self-Satisfaction (satisfaction with the learning outcome,peace,happiness) to follow the learning process.

Quotations from teachers' views are given below.

I determine the information according to the its effect on learning. The permanence of the information is important. I would follow the process by making the information that is useful and interesting to me be permanent to remember. T 29

"Note-taking and underlining are the most important activities that increase my attention. Besides, telling others what I learned is the most important method to understand whether I learn best or not." T15

"The length of the subject and being verbal or numerical influence my learning process.It is useul to me knowing how I can learn the information in most permenant way. I prefer to underline and create keywords most."T25

"The most common method I use while learning is summarizing with short notes and to underline what I see important or to save on my phone to read later. My aim is to make learning easier and more permanent. I evaluate myself according to self satisfaction."T44

\section{The opinions of the teachers regarding the question of "What are the opinions of teachers on how they} are motivated to learn?

The frequency results of the opinions of the teachers regarding the question of "What are the opinions of teachers on how they are motivated to learn? are given as follows.

Table 5. The opinions of teachers regarding "What are the opinions of teachers on how they are motivated to learn?

\begin{tabular}{|l|lcl|}
\hline $\begin{array}{l}\text { Themes } \\
\text { (Categories) }\end{array}$ & Codes & $\mathrm{f}$ & $\%$ \\
\hline $\begin{array}{l}\text { Motivation } \\
\text { to learn }\end{array}$ & $\begin{array}{l}\text { Thinking about the gain at the end of the study } \\
\text { (success, happiness, trust, inner satisfaction, practicality } \\
\text { respectability,to be useful to the student). } \\
\text { T44,T4,T26,T22,T11,T10,T18,T9,T13,T33,T34,T28, } \\
\text { T27,T25,T31,T30,T42,T35,T32,T41,T29,T2,T15,T36,T3 }\end{array}$ & \\
\cline { 2 - 4 } & $\begin{array}{l}\text { Intrinsic motivation } \\
\text { (learning desire, curiosity, liking to learn, }\end{array}$ & \\
\end{tabular}




\begin{tabular}{|c|c|c|}
\hline $\begin{array}{l}\text { personal satisfaction) } \\
\mathrm{T} 20, \mathrm{~T} 2, \mathrm{~T} 1, \mathrm{~T} 43, \mathrm{~T} 17, \mathrm{~T} 19, \mathrm{~T} 24, \mathrm{~T} 37, \mathrm{~T} 38, \mathrm{~T} 39, \mathrm{~T} 33, \mathrm{~T} 3, \mathrm{~T} 12, \\
\mathrm{~T} 5, \mathrm{~T} 26, \mathrm{~T} 44, \mathrm{~T} 6, \mathrm{~T} 18\end{array}$ & 18 & 40,90 \\
\hline $\begin{array}{l}\text { Believing to bring personal and professional contribution } \\
\text { T35,T29,T15,T20,T30,T19,T24,T33,T3,T13, } \\
\text { T22,T21,T41 }\end{array}$ & 13 & 29,54 \\
\hline $\begin{array}{l}\text { A regular environment and appropriate time } \\
\mathrm{T} 36, \mathrm{~T} 28, \mathrm{~T} 3, \mathrm{~T} 8, \mathrm{~T} 7, \mathrm{~T} 21\end{array}$ & 6 & 13,63 \\
\hline $\begin{array}{l}\text { Making enjoyable with the activities liked } \\
\mathrm{T} 25, \mathrm{~T} 28, \mathrm{~T} 34, \mathrm{~T} 16, \mathrm{~T} 13, \mathrm{~T} 10\end{array}$ & 6 & 13,63 \\
\hline $\begin{array}{l}\text { Consider the studying as a condition of success } \\
\text { T35,T42,T23 }\end{array}$ & 4 & 9,09 \\
\hline $\begin{array}{l}\text { Worth to learn } \\
\mathrm{T} 30, \mathrm{~T} 36, \mathrm{~T} 22, \mathrm{~T} 44\end{array}$ & 4 & 9,09 \\
\hline $\begin{array}{l}\text { Considering the needs } \\
\mathrm{T} 40, \mathrm{~T} 14, \mathrm{~T} 26\end{array}$ & 4 & 9,09 \\
\hline $\begin{array}{l}\text { External motivation } \\
\text { T13,T26 }\end{array}$ & 2 & 4,54 \\
\hline
\end{tabular}

When the Table 5 is analyzed,It is understood that teachers are motivated to learn thinking about the gain at the end of the study (success, happiness, trust, inner satisfaction, practicality respectability, to be useful to the student) and then Intrinsic motivation (learning desire, curiosity, liking to learn, personal satisfaction.

Quotations from teachers' opinions are given below.

"The sense of being successful, producing a project and the pleasure of producing solutions are the most motivating impulses for me. "T4

"I'm motivated by respect for my profession and myself." T41

"What I will learn is meaningful for me as it contributes to my personal development. Success is also important, but more self-confidence is more important than success. It automatically brings success. "T30

"I am motivated to learn by thinking "Learning will contribute to me in a positive way, I will be happy and peaceful at the end of learning, I will be more beneficial to my environment, I will have great time in my learning process, my stress will decrease etc." T13

5. The opinions of the teachers regarding the question of What are the opinions of teachers on how they continue their learning aspiration and determination?

The frequency results of the opinions of the teachers regarding the question of "What are the opinions of teachers on how they continue their learning aspiration and determination? are given as follows.

Table 6. The opinions of teachers regarding "What are the opinions of teachers on how they continue their learning aspiration and determination?

\begin{tabular}{|l|l|}
\hline $\begin{array}{l}\text { Theme } \\
\text { (Categories) }\end{array}$ & Codes \\
\hline $\begin{array}{l}\text { Learning } \\
\text { aspiration and }\end{array}$ & $\begin{array}{l}\text { According to the learning gain at the end of the study } \\
\text { (happiness, belief of success, contribution to individual }\end{array}$ \\
\hline
\end{tabular}


Arslan,F. (2019). The investigation of self directed learning skills of teachers in Kartepe (The District of Kocaeli In Turkey) : A qualitative study. International Journal of Educational Research Review,4(4),525-535.

\begin{tabular}{|c|c|c|c|}
\hline \multirow[t]{7}{*}{ determination } & $\begin{array}{l}\text { and professional development, applicability in daily life) } \\
\text { T15,T32,T4,T26,T22,T10,T9,T7,T8,T6,T13,T40,T3,T36, } \\
\text { T33,T34,T28,T27,T25,T24,T23,T31,T30,T29,T42,T35,T44 }\end{array}$ & 27 & 61,36 \\
\hline & $\begin{array}{l}\text { Intrinsic motivation } \\
\text { (learning desire, curiosity, need, trust, dignity) } \\
\mathrm{T} 22, \mathrm{~T} 5, \mathrm{~T} 11, \mathrm{~T} 10, \mathrm{~T} 18, \mathrm{~T} 13, \mathrm{~T} 40, \mathrm{~T} 33, \mathrm{~T} 38, \mathrm{~T} 37 \\
\mathrm{~T} 36, \mathrm{~T} 27, \mathrm{~T} 24, \mathrm{~T} 17, \mathrm{~T} 30, \mathrm{~T} 43, \mathrm{~T} 1, \mathrm{~T} 44\end{array}$ & 18 & 40,90 \\
\hline & $\begin{array}{l}\text { Thinking that learning is his / her responsibility } \\
\mathrm{T} 4, \mathrm{~T} 9, \mathrm{~T} 16, \mathrm{~T} 23, \mathrm{~T} 19, \mathrm{~T} 43, \mathrm{~T} 2, \mathrm{~T} 35, \mathrm{~T} 20\end{array}$ & 9 & 20,45 \\
\hline & $\begin{array}{l}\text { Following in ambitious and determined people's footsteps } \\
\mathrm{T} 21, \mathrm{T3}\end{array}$ & 2 & 4,54 \\
\hline & $\begin{array}{l}\text { I have no idea } \\
\text { T14,T41 }\end{array}$ & 2 & 4,54 \\
\hline & $\begin{array}{l}\text { Keeping expectations low } \\
\text { T12 }\end{array}$ & 1 & 2,27 \\
\hline & $\begin{array}{l}\text { According to the pleasure of the work done } \\
\text { T2 }\end{array}$ & 1 & 2,27 \\
\hline
\end{tabular}

When the Table 6 is analyzed, It is understood that teachers initially continue their learning aspiration and determination according to the learning gain at the end of the study (happiness, belief of success, contribution to individual and professional development, applicability in daily life) and then Intrinsic motivation (learning desire, curiosity, need, trust, dignity).

Quotations from teachers' views are given below.

"Thinking that learning is a lifelong need "T18

"Since I know that learning continues for a lifetime, I like to exchange ideas with the people in all kinds of social groups and I have a curious personality in both my professional and personal lives.My aspiration and determination for learning will be constant "T24

"I continue my desire to learn until I get a positive result. I focus more on the information that I think will contribute to professional and personal matters. It is very important that knowledge works in my daily life." T8

"I continue by considering the contribution to my life and professional development."T9

"Since I regard giving up as failing, I will continue."T8

\section{Result, Discussion, and Suggestions}

When the teachers'opinions on self directed learning are evaluated;

- It is interpreted that teachers mostly prefer "Art and Socio Cultural Activities (chess, cinema, instrument, folk dances, concert)" then reading about personal development and interest regarding their individual development in the lifelong learning process. They tend "participation in seminars, in-service and distance trainings" at first ;" researching and keeping updated on the latest development about their branches" secondly in terms of their professional development in the lifelong learning process.

- It is understood that teachers plan their activities according to topics of interest initially and bearing profit professionally next while planning their learning activities.

- It is inferred that first of all ,teachers identify their learning strategies "According to the its effect on learning information (being permanent, easy to remember) and "determining according to the 
Arslan,F. (2019). The investigation of self directed learning skills of teachers in Kartepe (The District of Kocaeli In Turkey) : A qualitative study. International Journal of Educational Research Review,4(4),525-535.

subject (subject length, content) in addition to evaluating learning outcomes with Self-Assessment (repetation, asking questions ,narrating the subjects and Self-Satisfaction (satisfaction with the learning outcome,peace,happiness) later to follow the learning process

- It is assumed that teachers are motivated to learn thinking about the gain at the end of the study (success, happiness, trust, inner satisfaction, practicability, respectability, to be useful to the student) primarily and then Intrinsic motivation (learning desire, curiosity, liking to learn, personal satisfaction.

- It is deduced that teachers initially continue their learning aspiration and determination according to the learning gain at the end of the study (happiness, belief of success, contribution to individual and professional development, applicability in daily life) and then Intrinsic motivation (learning desire, curiosity, need, trust, dignity).

The findings of the study which investigating the teachers'opinions on self directed learning represent each phase of self-directed learning. and in this respect, it conforms to the Knowles' (1975) best-known and most popular definition of self-directed learning. According to Knowles: In its broadest meaning, "selfdirected learning" describes a process in which individuals take the initiative, with or without the help of others, in diagnosing their learning needs, formulating learning goals, identifying human and material resources for learning, choosing and implementing appropriate learning strategies, and evaluating learning outcomes. (p. 18).

There is almost no study involving teachers' views on self-directed learning in the literature, The results of this study are mostly consistent with the study of Coşkun and Demirel (2012) which investigates teachers' views on self-directed learning skills. This study, in which qualitative research method was used, was conducted with 32 prospective teachers studying at a state university. According to the results of the research, it is revealed that teacher candidates generally feel the need to learn about the subjects that they are interested and that contribute to their professional and personal development. It was determined that preservice teachers determined their learning goals according to the situation in which the information will be used and the gains at the end of the study; the learning plans according to the lesson / subject to be studied and the time they study efficiently. They have stated that they act according to the criteria in the choice of learning strategies to be used during learning is being appropriate to the subject, their effects on the learning of the information and the time required to use. Participants also stated that they followed the learning processes according to whether to study efficiently or not and the time spent on learning and they evaluated the learning results according to the exam results. It was determined that the participants exhibited desired self directed behaviours in terms of motivation, persistence (insistence on learning) and taking responsibility for learning.

The effect of self directed learning on teachers'professional development is consistent with the study in which Şahin (2010) investigated the effect of teaching style preferences, gender, the lenght of service, selfefficacy perceptions and the level of self directed readiness of primary school teachers on their professional competencies . a significant difference was found between the professional competencies of the primary school teachers regarding the their readiness to self-directed learning in the study. According to this, the professional competence levels of teachers with high self-directed learning were found to be higher than those of teachers with low self-directed learning. It can be said that the level of readiness for self-directed learning of primary school teachers leads to a difference in the level of professional competence. If we evaluate the findings of the qualitative study, it is seen that they are open to all kinds of learning that will support their individual and professional development.

All learning activities of teachers within and outside the school such as in-service training, seminars at the begining and at the end of the year should be organized by taking into consideration the stages of self directed learning. In other words, teachers should take the initiative to identify learning needs in all kinds of learning processes, to determine learning objectives, to identify human and material resources for learning, to select and implement appropriate learning strategies and to evaluate learning outcomes.

\section{Limitations of the study}

- This study would be implemented in more than two schools with more teachers from different branches to get more general results. 
Arslan,F. (2019). The investigation of self directed learning skills of teachers in Kartepe (The District of Kocaeli In Turkey) : A qualitative study. International Journal of Educational Research Review,4(4),525-535.

- The interviews took at most 14 minutes because of the explanations from the researcher to make the questions clearer in spite of the alternative sub-questions. These explanations could direct the teachers' answers less or more.

\section{References}

Benson, P. (2001). Teaching and researching autonomy in language learning, Essex, UK: Pearson Education Limite.

Brockett, R. G., \& Hiemstra, R. (1991). Self-direction in adult learning: Perspectives in theory, research, and practice. New York: Routledge.

Coşkun, D. Y. \& Demirel, M. (2012). Üniversite öğrencilerinin yaşam boyu öğrenme eğilimleri. Hacettepe Üniversitesi Ĕ̆itim Fakültesi Dergisi, 42, 108-120.

Knowles, M. S. (1975). Self-directed learning: A guide for learners and teachers. New York, NY: Association Press and Cambridge Book Co.

Merriam, S. B. (2001). Andragogy and self-directed learning: Pillars of adult learning. In S. B. Merriam (Ed.), The new update on adult learning theory (New Directions for Continuing Education, Number 89, pp. 3-13). San Francisco, CA: JosseyBass.

Owen, T. R. (2002). Self-directed learning in adulthood: A literature review (Report No. CE 082822). Morehead, KY: Morehead State University. (ERIC Document Reproduction Services No. ED 441000).

Ponton, M. K., \& Carr, P. B. (1996). Understanding and promoting autonomy in self directed learning. Current Research in Social Psychology, 2, 15-22.

Porter, B. D. (2014). Religious educators' expernences with self-directed learning. (Doctor of Philosophy) Proquest Thesis and Dissertations (UMI Number: 3683596)

Şahin, E. (2010). İlköğretim sını öğretmenlerinin öğretim stili tercihlerinin, cinsiyetlerinin, mesleki kıdemlerinin, özyeterlik algılarının ve özyönetimli öğrenmeye hazırbulunuşluk düzeylerinin mesleki yeterlikleri üzerindeki etkisi. ( Doctor of Education) Proquest Thesis and Dissertations.( UMI Number: 04707201)

Yıldırım, A. \& Şimşek, H. (2011). Sosyal bilimlerde nitel araştırma yöntemleri. Ankara: Seçkin Yay. 